\title{
Longitudinal study of winter mortality disease in Sydney rock oysters Saccostrea glomerata
}

\author{
Zoe B. Spiers ${ }^{1}$, Melinda Gabor ${ }^{1}$, Shayne A. Fell ${ }^{1}$, Ryan B. Carnegie ${ }^{2}$, Michael Dove ${ }^{3}$, \\ Wayne O'Connor ${ }^{3}$, Jane Frances ${ }^{3}$, Jeffrey Go ${ }^{1}$, Ian B. Marsh ${ }^{1}$, Cheryl Jenkins ${ }^{1, *}$ \\ ${ }^{1}$ NSW Department of Primary Industries, Elizabeth Macarthur Agricultural Institute, Menangle, New South Wales 2568, \\ Australia \\ ${ }^{2}$ Virginia Institute of Marine Science, College of William and Mary, Gloucester Point, Virginia 23062-1346, USA \\ ${ }^{3}$ NSW Department of Primary Industries, Port Stephens Fisheries Institute, Port Stephens, New South Wales 2315, Australia
}

\begin{abstract}
Winter mortality (WM) is a poorly studied disease affecting Sydney rock oysters Saccostrea glomerata in estuaries in New South Wales, Australia, where it can cause significant losses. WM is more severe in oysters cultured deeper in the water column and appears linked to higher salinities. Current dogma is that WM is caused by the microcell parasite Bonamia roughleyi, but evidence linking clinical signs and histopathology to molecular data identifying bonamiasis is lacking. We conducted a longitudinal study between February and November 2010 in 2 estuaries where WM has occurred (Georges and Shoalhaven Rivers). Results from molecular testing of experimental oysters for Bonamia spp. were compared to clinical disease signs and histopathology. Available environmental data from the study sites were also collated and compared. Oyster condition declined over the study period, coinciding with decreasing water temperatures, and was inversely correlated with the presence of histological lesions. While mortalities occurred in both estuaries, only oysters from the Georges River study site showed gross clinical signs and histological changes characteristic of WM (lesions were prevalent and intralesional microcell-like structures were sometimes noted). PCR testing for Bonamia spp. revealed the presence of an organism belonging to the B. exitiosa-B. roughleyi clade in some samples; however, the very low prevalence of this organism relative to histological changes and the lack of reactivity of affected oysters in subsequent in situ hybridisation experiments led us to conclude that this Bonamia sp. is not responsible for WM. Another aetiological agent and a confluence of environmental factors are a more likely explanation for the disease.
\end{abstract}

KEY WORDS: Bonamia roughleyi $\cdot$ Microcell-like structure $\cdot$ Lesion $\cdot$ Haemocyte

\section{INTRODUCTION}

Winter mortality is a poorly studied disease affecting Sydney rock oysters Saccostrea glomerata (Gould 1850) in the southern half of its cultivation range in New South Wales (NSW), Australia. The disease was first observed in 1923 in the Georges River and regularly causes economically significant oyster losses during winter and early spring. Winter mortality disease, along with Queensland unknown (QX) disease caused by Marteilia sydneyi, is considered among the key contributing factors for $S$. glomerata production declines since the mid-1970s (Nell 2007).

The first investigation into the potential causes of winter mortality was carried out between 1924 and 1925 (Roughley 1926), where it was determined that cold temperatures were a contributing but indirect cause of mortality. Subtidal oysters were found to be more prone to winter mortality than intertidal oysters, suggesting that prolonged exposure to an agent 
within the water column was important in inducing clinical disease (Roughley 1926). More recent observations (Wolf 1967), and controlled studies in which raising the growing height of Saccostrea glomerata had a significant positive effect on oyster survival (Smith et al. 2000), corroborated the earlier findings. Winter mortality occurs primarily in oysters 2 to $3 \mathrm{yr}$ of age in areas of high salinity (Wolf 1967, Nell \& Perkins 2006). Oyster growers currently move oyster stocks to upstream leases prior to the winter season to avoid winter mortality losses (Smith et al. 2000, Nell 2007).

Winter mortality is characterised by the presence of pustules, abscesses and ulcerations, and these lesions have been reported in various tissues including the mantle, palps, gills, adductor muscle, gonad, digestive diverticulum and alimentary tract (Roughley 1926, Farley et al. 1988, Bower 2012). Microscopic observations of haemocyte accumulations within these lesions led Roughley (1926) to infer that the cause of disease was an unidentified bacterial agent; however, a histological investigation of winter mortality conducted some decades later indicated that the causative agent was a protistan 'microcell' parasite (Farley et al. 1988). This conclusion was based on observations of small (1-2 $\mu \mathrm{m}$ diameter), spherical, single-celled organisms with eccentric nuclei that were both intracellular (primarily within haemocytes) and associated with lesions (Farley et al. 1988).

The identity of the microcells associated with winter mortality has been the subject of some confusion. Farley et al. (1988) classified the Saccostrea glomerata parasite as Mikrocytos roughleyi based on comparisons with other microcell organisms of the genera Mikrocytos and Bonamia. Two major observations that led to this classification were that (1) both $M$. mackini, the causative agent of Denman Island disease in Crassostrea gigas, and M. roughleyi of $S$. glomerata cause focal abscesses, whereas $B$. ostreae infections in the European flat oyster Ostrea edulis are more disseminated; and (2) Mikrocytos spp. only infect crassostreid oysters while Bonamia spp. only infect ostreid oysters. Indeed, Brock (1990) demonstrated that the genus Ostrea is more distant from Crassostrea and Saccostrea than the latter 2 genera are from each other. Therefore, the second assumption made by Farley et al. (1988) has since been violated given that Mikrocytos spp. have been found to infect O. edulis (Bower et al. 1997, Gagné et al. 2008), and conversely, 1 or more Bonamia spp. have been shown to infect $C$. ariakensis (C. rivularis) (Cochennec et al. 1998, Audemard et al. 2008). The first assumption has also been challenged via the assertion that lesion morphology cannot be used to differentiate between microcell pathogens occurring in different host species due to variations in tissue structure (Cochennec-Laureau et al. 2003).

Current dogma is that winter mortality is caused by Bonamia roughleyi, a member of the phylum Haplosporidia (Carnegie \& Cochennec-Laureau 2004, López-Flores et al. 2007). Reclassification of Mikrocytos roughleyi into the genus Bonamia was based on ultrastructural observations of a parasite within Saccostrea glomerata gill and digestive gland tissue (Cochennec-Laureau et al. 2003). In that study, mitochondria and haplosporosomes were observed within parasites, while $M$. mackini is amitochondriate and lacks haplosporosomes (Hine et al. 2001). These observations, combined with molecular testing, which revealed the presence of Bonamia sp. DNA within $S$. glomerata oysters, led to the conclusion that $M$. roughleyi belonged in the genus Bonamia. Nonetheless, the organism $M$. roughleyi, first described by Farley et al. (1988), appears to be somewhat different from that described by Cochennec-Laureau et al. (2003), in that $M$. roughleyi is 1 to $2 \mu \mathrm{m}$ in size and spherical, rather than the 3 to $5 \mu \mathrm{m}$, ovoid and occasionally multinucleate organism observed in the latter study. The ultrastructure of the organism in the study by Cochennec-Laureau et al. (2003) could be considered consistent with a number of different organisms. Indeed, these morphological and ultrastructural descriptions combined with the fact that the parasites resided primarily in the digestive tubules and gill, could be considered consistent with Marteilia sydneyi daughter cells (Kleeman et al. 2002), a haplosporosome-containing paramyxean parasite that is prevalent in $S$. glomerata in a number of NSW estuaries. A further question regarding the study by Cochennec-Laureau et al. (2003) is whether molecular testing and ultrastructural investigations were conducted on tissue derived from the same oysters. Thus, while a Bonamia sp. has been detected within S. glomerata oysters using molecular methods, its connection with winter mortality and the original disease descriptions (Roughley 1926, Farley et al. 1988) have not been fully established. Molecular identification of the aetiological agent of winter mortality has been further confounded by the fact that $B$. roughleyi found in NSW oysters does not appear to be easily distinguishable from $B$. exitiosa, the cause of bonamiosis in Ostrea chilensis based on 18S rRNA gene sequences (Corbeil et al. 2006, Hill et al. 2010).

The State Veterinary Diagnostic Laboratory at the Elizabeth Macarthur Agricultural Institute (NSW) 
has received numerous Saccostrea glomerata samples for winter mortality diagnosis from estuaries prone to the disease over a period of approximately 5 yr. Diagnostic testing, consisting of a Bonamia genus-specific PCR, failed to return positive results in all but a very small proportion of clinical cases during this period. In light of these findings and to address the knowledge gaps surrounding winter mortality, we conducted a longitudinal investigation in $2 \mathrm{NSW}$ estuaries: the Georges River, where the disease was first described (and occurs each year), and the Shoalhaven River, which also suffers regular losses of $S$. glomerata due to winter mortalities. In this study, we examined molecular, histological and environmental data to further characterise the causes and nature of the disease.

\section{MATERIALS AND METHODS}

\section{Experimental oysters and sampling strategy}

Saccostrea glomerata stocks deployed in early February 2010 to the Georges River originated from the Camden Haven River on the mid-North coast of NSW (Fig. 1). Oysters sourced from this location were considered naïve to winter mortality since the disease is not known to occur in this estuary. These oysters were translocated to the Clyde River in 2008 and cultivated on an oyster farm until they reached a susceptible age (>2 yr old; Lauckner 1983). The Clyde River is a winter mortality-prone area (Fig. 1) and was chosen as an intermediate cultivation site for oysters sent to the Georges River in the event that prior exposure to the winter mortality agent increased disease susceptibility (Hand et al. 1998, Smith et al. 2000, Nell 2007).

Oysters used for the Shoalhaven River trial were wild stock collected from this estuary. During their cultivation in the Shoalhaven River in 2008 and 2009, they were farmed at locations affected by winter mortality. The study sites were located in Quibray Bay in the Georges River, and Berrys Bay in the Shoalhaven River (Fig. 1). Approximately 500 oysters were placed in trays and deployed at the study sites. Live oysters $(n=30)$ were randomly sampled from each study site before deployment and at each designated time point thereafter up until November 2010. Oysters were sampled approximately every $3 \mathrm{wk}$ during this period in the event that the window of infection associated with winter mortality was brief. A sample size of 30 was selected to give a $95 \%$ chance of detecting disease in the event of low $(5 \%)$

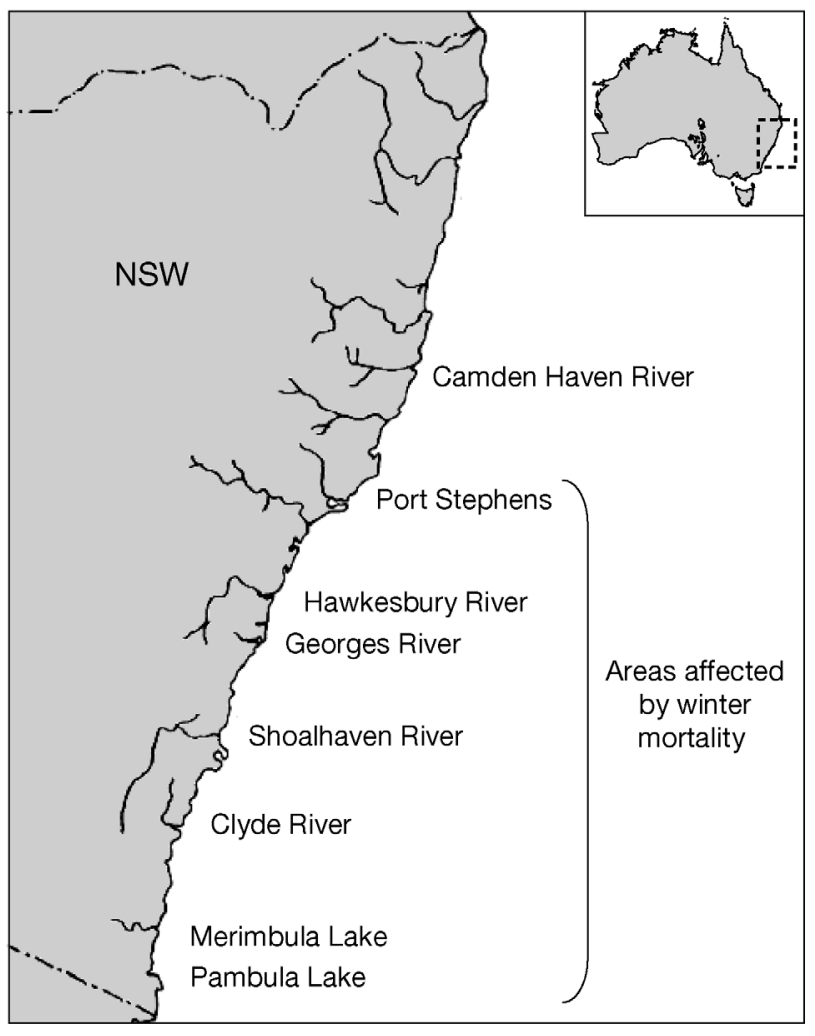

Fig. 1. Cultivation areas for Saccostrea glomerata and the major estuaries in New South Wales (NSW), Australia, affected by winter mortality. The Georges and Shoalhaven Rivers were chosen for the longitudinal study

prevalence (Cannon \& Roe 1982). Samples were placed in mesh bags and stored on ice for shipment to the laboratory for processing.

\section{Sample processing}

The external surfaces of the oysters were scrubbed and rinsed to remove excess debris, and the oysters were opened with sterile shucking knives. The adductor muscles were severed using disposable scalpel blades, and oysters were transferred to sterile petri dishes for dissection. Oysters were examined for gross pathology (lesions), and transverse sections were made in order to score oyster condition. Condition scores were assigned based on the thickness of the gonadal tissue on a scale of 1 to 5 ( $1=$ oyster is thin, lacking any appreciable gonadal tissue; $2=$ gonad is present but transparent, digestive gland is clearly visible; $3=$ moderate layer of gonad surrounding digestive gland; $4=$ well developed gonad, digestive gland not visible; $5=$ oyster is fully ripe, digestive gland not visible). Transverse sections containing 
gill/palp, mantle, gonad and digestive gland were taken for preservation in $100 \%$ ethanol (for future molecular studies) and 10\% neutral-buffered formalin (for histology). For immediate molecular testing, oyster heart and approximately $5 \mathrm{mg}$ each of digestive gland and gill tissue were dissected from each oyster and pooled in a sterile microcentrifuge tube for DNA extraction. For histology, tissues fixed for 24 to $48 \mathrm{~h}$ in neutral-buffered formalin were embedded in paraffin, sectioned and stained with haematoxylin and eosin (H\&E). Paraffin blocks of the winter mortality disease type material (Farley et al. 1988) were also sectioned and stained with H\&E for comparison. The disease type material had been collected in 1965 from Woolooware Bay (adjacent to Quibray Bay) in the Georges River by P. Wolf (Farley et al. 1988).

Spearman's correlation coefficient was used to determine whether there was a correlation between oyster condition score and the presence or absence of histological lesions consistent with winter mortality in Georges River oysters. For the analysis, lesions were scored either as 0 (no lesions) or 1 (lesions present). Calculations were performed with GraphPad Prism ${ }^{\circledR}$ Version 4.02.

\section{Collection of environmental data}

Weekly rainfall data were obtained from the Bureau of Meteorology website (www.bom.gov.au/ watl/about/index.shtml) and were collected from stations located within $10 \mathrm{~km}$ of each study site. Water temperature, salinity and phytoplankton data for the Georges River study site were collected from Quibray Bay during periodic safety testing conducted by the NSW Food Authority (Newington, NSW). Phytoplankton data were not available for the Shoalhaven River study site in Berrys Bay; however, water temperature and salinity measurements were made during oyster sample collection. Additional salinity measurements were also made during routine checks of the study site (O'Neill 2011). The number of dead oysters (empty valves) in experimental units was counted at the end of the study period.

\section{PCR analyses and sequencing}

DNA was extracted with a Qiagen DNeasy Blood and Tissue kit according to the manufacturer's instructions. PCR reactions for all targets were prepared in a total volume of $25 \mu \mathrm{l}$ containing $1 \times$ BioTaq buffer, $200 \mu \mathrm{M}$ dNTPs, $2.5 \mathrm{mM} \mathrm{MgCl}{ }_{2}, 400 \mathrm{nM}$ each primer, $1 \mathrm{U}$ of BioTaq DNA polymerase (Bioline) and $2 \mu \mathrm{l}$ of DNA extract. Cycling parameters for each PCR assay are listed in Table 1. A PCR assay for Saccostrea glomerata was run on each DNA extract to ensure that samples did not contain PCR inhibitors. Total DNA extracts from $S$. glomerata tissues known to be positive by sequence analysis for Bonamia sp., Marteilia sydneyi, or an unidentified Haplosporidium sp. detected locally in NSW were used as PCR-positive controls in the relevant assays. Negative controls contained nuclease-free water instead of DNA, or contained PCR cocktail only. To obtain 18S rDNA sequence data for the Georges River Bonamia sp. and the Haplosporidium sp., the universal eukaryote primers 18S A (forward) and 18S B (reverse) were used in combination with either the Bonamia genusspecific primers or primers specific for the Haplosporidium sp. (Table 1). All reaction products were visualised after electrophoresis on $2 \%$ agarose gels stained with ethidium bromide. Where required, PCR products were purified using the QIAquick PCR purification kit (Qiagen) and sequenced at the Australian Genome Research Facility using BigDye terminator version 3.1 (Applied Biosystems).

\section{In situ hybridisation}

In situ hybridisation (ISH) was carried out using a previously described method (Stokes \& Burreson $1995)$ with the following modifications. For detection of organisms in the Bonamia exitiosa-B. roughleyi clade, a cocktail of 3 probes (Table 1) was employed, with each diluted to a final concentration of $2 \mathrm{ng}^{-1} \mathrm{l}^{-1}$ in hybridisation buffer. To ensure that the tissue sections utilised in this study contained viable RNA for probe hybridisation, ISH was also conducted using universal eukaryotic probes (Table 1). For detection of the Haplosporidium sp. organism, the SSO1318 probe (Table 1) was used at a final concentration of $5 \mathrm{ng} \mathrm{ul}^{-1}$ in the hybridisation buffer. Hybridisation was performed in a Hybaid Omnislide humidity chamber. The anti-digoxigenin antibody was sourced from Roche. Goat serum was used in place of sheep serum for blocking. Sections from Bonamia sp.-infected Crassostrea ariakensis and $H$. costale-infected $C$. virginica were used as positive controls. Sections from infected oysters with no probe added and sections from uninfected oysters with probe added were used as negative controls. Test sections consisted of samples positive for Bonamia sp. by PCR and samples with significant histological lesions displaying evidence of microcell-like structures. 
Table 1. PCR primers and in situ hybridisation (ISH) probes used in this study. DIG: digoxigenin. NA: not applicable

\begin{tabular}{|c|c|c|c|c|}
\hline $\begin{array}{l}\text { Primer or } \\
\text { probe }\end{array}$ & Sequence $\left(5^{\prime}-3^{\prime}\right)$ & PCR parameters & $\begin{array}{l}\text { Product } \\
\text { size (bp) }\end{array}$ & Source \\
\hline \multicolumn{5}{|c|}{ Bonamia genus-specific PCR } \\
\hline Bo 1 & CCT AGG GTG ACC CCT CTG & $\begin{array}{l}94^{\circ} \mathrm{C}, 3 \mathrm{~min}(\times 1) \\
94^{\circ} \mathrm{C}, 30 \mathrm{~s} ; \\
58^{\circ} \mathrm{C}, 30 \mathrm{~s}_{i}(\times 40) \\
72^{\circ} \mathrm{C}, 45 \mathrm{~s}_{i}\end{array}$ & 237 & Marty et al. (2006) \\
\hline Bo 4 & GGG TCA AAC TCG TTG AAC G & $72^{\circ} \mathrm{C}, 5 \min (\times 1)$ & & Marty et al. (2006) \\
\hline \multicolumn{5}{|c|}{ Saccostrea glomerata PCR } \\
\hline SRO18SsmF & AGT ACC TGC CCA GTG CAA AA & $\begin{array}{l}94^{\circ} \mathrm{C}, 3 \mathrm{~min}(\times 1) \\
94^{\circ} \mathrm{C}, 20 \mathrm{~s}_{i} \\
55^{\circ} \mathrm{C}, 20 \mathrm{~s}_{i}(\times 35) \\
65^{\circ} \mathrm{C}, 20 \mathrm{~s}_{i}\end{array}$ & 135 & This study \\
\hline SRO18SsmR & GCT GCT CAA AGC AAG AGA CA & $65^{\circ} \mathrm{C}, 5 \min (\times 1)$ & & This study \\
\hline \multicolumn{5}{|c|}{ Generic haplosporidian PCR } \\
\hline Hap F1 & GTT CTT TCW TGA TTC TAT GMA & $\begin{array}{l}95^{\circ} \mathrm{C}, 2 \mathrm{~min}(\times 1) \\
95^{\circ} \mathrm{C}, 30 \mathrm{~s}_{i} \\
54^{\circ} \mathrm{C}, 30 \mathrm{~s}_{i}(\times 35) \\
72^{\circ} \mathrm{C}, 60 \mathrm{~s}_{i}\end{array}$ & $329-343$ & Renault et al. (2000) \\
\hline Hap R4 & AAT TRC AAT CRY CTA TCC C & $72^{\circ} \mathrm{C}, 5 \min (\times 1)$ & & This study \\
\hline \multicolumn{5}{|c|}{ Haplosporidium costale-like PCR } \\
\hline SSO-A-NSW & CAC GAC TTT GGC AGA TGT TTT G & $\begin{array}{l}95^{\circ} \mathrm{C}, 2 \mathrm{~min}(\times 1) \\
95^{\circ} \mathrm{C}, 30 \mathrm{~s}_{i} \\
59^{\circ} \mathrm{C}, 30 \mathrm{~s}_{i}(\times 35) \\
72^{\circ} \mathrm{C}, 90 \mathrm{~s}_{i}\end{array}$ & 559 & $\begin{array}{l}\text { This study (modified } \\
\text { from Stokes \& } \\
\text { Burreson 2001) }\end{array}$ \\
\hline SSO-B & CGA ACA AGC GCT AGC AGT ACA T & $72^{\circ} \mathrm{C}, 5 \min (\times 1)$ & & Stokes \& Burreson (2001) \\
\hline \multicolumn{5}{|c|}{ Universal 18S rDNA primers for sequencing } \\
\hline $18 \mathrm{~S} \mathrm{~A}$ & ACC TGG TTG ATC CTG CC & $\begin{array}{l}94^{\circ} \mathrm{C}, 3 \mathrm{~min}(\times 1) \\
94^{\circ} \mathrm{C}, 30 \mathrm{~s}_{i} \\
58^{\circ} \mathrm{C}, 60 \mathrm{~s}_{i}(\times 35) \\
72^{\circ} \mathrm{C}, 60 \mathrm{~s}_{i}\end{array}$ & NA & Medlin et al. (1988) \\
\hline $18 \mathrm{~S} \mathrm{~B}$ & TGA TCC TTC TGC AGG TTC ACC TAC & $72^{\circ} \mathrm{C} ; 5 \min (\times 1)$ & & Medlin et al. (1988) \\
\hline \multicolumn{5}{|c|}{ Universal non-metazoan PCR } \\
\hline Euk 581F & GTG CCA GCA GCC CCG & $\begin{array}{l}94^{\circ} \mathrm{C}, 3 \mathrm{~min}(\times 1) \\
94^{\circ} \mathrm{C}, 30 \mathrm{~s}_{i} \\
49^{\circ} \mathrm{C}, 60 \mathrm{~s}_{i}(\times 35) \\
72^{\circ} \mathrm{C}, 60 \mathrm{~s}_{i}\end{array}$ & 544 & Carnegie et al. (2003) \\
\hline Euk 1134R & TTT AAG TTT CAG CCT TGC G & $72^{\circ} \mathrm{C}, 5 \min (\times 1)$ & & Carnegie et al. (2003) \\
\hline \multicolumn{5}{|c|}{ Mikrocytos genus-specific $\mathbf{P C R}^{\mathrm{a}}$} \\
\hline Mikrocytos-F & AGA TGG TTA ATG AGC CTC C & $\begin{array}{l}94^{\circ} \mathrm{C}, 3 \min (\times 1) \\
94^{\circ} \mathrm{C}, 30 \mathrm{~s} ; \\
60.5^{\circ} \mathrm{C}, 1 \mathrm{~min}(\times 35)\end{array}$ & $546-523$ & Carnegie et al. (2003) \\
\hline Mikrocytos-R & GCG AGG TGC CAC AAG GC & $72^{\circ} \mathrm{C}, 1 \mathrm{~min}$ & & Carnegie et al. (2003) \\
\hline \multicolumn{5}{|c|}{ Marteilia sydneyi PCR } \\
\hline PRO 2 & TCA AGG GAC ATC CAA CGG TC & $\begin{array}{l}94^{\circ} \mathrm{C}, 3 \mathrm{~min}(\times 1) \\
94^{\circ} \mathrm{C}, 20 \mathrm{~s}_{i} \\
55^{\circ} \mathrm{C}, 20 \mathrm{~s}_{i}(\times 35) \\
65^{\circ} \mathrm{C}, 20 \mathrm{~s}_{i}\end{array}$ & 195 & Kleeman \& Adlard (2000) \\
\hline LEG 1 & CGA TCT GTG TAG TCG GAT TCC G & $65^{\circ} \mathrm{C}, 5 \min (\times 1)$ & & Kleeman \& Adlard (2000) \\
\hline \multicolumn{5}{|c|}{ B. exitiosa-B.'roughleyi' clade ISH } \\
\hline CaBon166 & DIG-CGA GCA GGG TTT GTC ACG TAT & NA & NA & Hill et al. (2010) \\
\hline CaBon461 & DIG-TTC CGA ATA GGC AAC CGA AG & & & Hill et al. (2010) \\
\hline CaBon1704 & DIG-CAA AGC TTC TAA GAA CGC GCC & & & Hill et al. (2010) \\
\hline \multicolumn{5}{|c|}{ Universal eukaryote ISH } \\
\hline Euk516 & 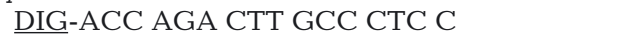 & NA & NA & Amann et al. (1990) \\
\hline Euk1195 & DIG-GGG CAT CAC AGA CCT G & & & Giovannoni et al. (1988) \\
\hline \multicolumn{5}{|c|}{ H. costale-like sp. ISH } \\
\hline SSO1318 & DIG-CGA ACA AGC GCT AGC AGT ACA T & NA & NA & Stokes \& Burreson (2001) \\
\hline
\end{tabular}




\section{RESULTS}

\section{Oyster condition, oyster mortalities and environmental observations}

Over the study period, the oysters in Quibray Bay (Georges River) experienced 10\% mortality. Oysters sampled from Quibray Bay displayed a gradual decline in condition between March and October (Fig. 2A). Gross clinical signs of disease consistent with prior descriptions of winter mortality were observed in Georges River oysters collected between early August and mid-October. Lesions were generally small ( $2 \mathrm{~mm}$ diameter) and consisted of yellow to brown spots on the gonad and mantle and/or abscess-like lesions (evident in cross-section) adjacent to the gut lumen. Enlarged palps were also noted in some oysters. Gross lesions were most prevalent in oysters sampled during early and late September with 5/30 ( 17\%) of oysters affected at each time point.

Oysters sampled from Berrys Bay (Shoalhaven River) experienced $13 \%$ mortality and showed an overall decline in mean condition score over the study period (Fig. 2B). Macroscopic lesions consistent with winter mortality were not observed in any oysters sampled from this location.

The environmental data collected for the Quibray Bay and Berrys Bay study sites are summarised in Fig. 2C-I. Water temperature at both sites dropped steadily from the time of deployment (February) until the end of winter (August) and began increasing in early spring (September; Fig. 2C,D). The Berrys Bay site, located in the more southerly Shoalhaven estuary, reached a low of $12^{\circ} \mathrm{C}$, while the water temperature in Quibray Bay did not get below $15^{\circ} \mathrm{C}$ during the study period. Oyster condition generally declined in parallel with water temperature; however, the appearance of macroscopic lesions consistent with winter mortality (Georges River samples only), were most obvious as the water began to warm in September.

The pattern of rainfall was similar between estuaries (Fig. 2E,F); however, the salinity in Quibray Bay (Fig. 2G) remained relatively high and stable (30$35 \mathrm{ppt}$ ) over the study period, while the salinity in Berrys Bay (Fig. 2H) was greatly affected by a heavy rainfall event in June (Fig. 2F) where it reached a low of 7 ppt. While an even larger rainfall event was recorded in Quibray Bay at this time, salinity levels were not impacted. Similarly, salinity levels at the beginning of the study period were much lower in Berrys Bay compared to Quibray Bay following heavy rainfall early in the month.
Phytoplankton are a primary food source for oysters, and therefore it was of interest to assess the levels of these organisms throughout the study period. Phytoplankton data were only available for the Quibray Bay study site, although a general seasonal trend was evident (Fig. 2I). Total phytoplankton levels were high $\left(4000\right.$ cells ml $\left.{ }^{-1}\right)$ in February towards the end of summer, coinciding with both high rainfall and high water temperatures. There was a general downtrend in phytoplankton levels in Quibray Bay during autumn and winter with a spike in cell count observed in June, coinciding with a heavy rainfall event. From July to early September, when rainfall and water temperatures were low, cell counts were $\leq 1000$ cells $\mathrm{ml}^{-1}$. Phytoplankton levels increased moderately toward the end of the study period from late September to October and in November (Fig. 2I).

\section{Histopathology}

A total of 381 and 355 individual oysters from the Georges and Shoalhaven Rivers, respectively, were examined for histopathology. The prevalence (\%) of microscopic lesions in oysters from each study site, and that were considered consistent with prior descriptions of winter mortality, is shown in Fig. 3. Affected oysters from the Georges River were characterised by the presence of hyperplasia, ulceration or erosion of the gut (stomach, intestine) epithelium and hypercellularity of the gut epithelium with activated haemocytes (abundant eosinophilic cytoplasm with eccentric nucleus). Similar changes were occasionally noted in the palps and gills. The characteristic changes noted in epithelia lining the alimentary tract, palps and gills began to appear in April and May but were most marked and prevalent (Fig. 3A) in the oysters examined from August to late September, with milder changes still evident in October.

Characteristic lesions in the palps can be seen in Fig. 4A, with multifocal epithelial ulceration and focal haemocyte accumulation. Fig. 4B displays marked haemocytic infiltrates along the submucosa of the intestine, extending into the submucosa, associated with marked epithelial proliferation and degeneration. In most oysters examined, Leydig tissue was plump, with minimal haemocyte infiltrations. Digestive glands were largely unaffected with the exception in minor variations in feeding status (dilation of lumena). Towards the end of the study, chronic epithelial changes extended to the digestive gland duct epithelium. In some cases, intralesional structures consistent with the appearance of microcells (Farley et al. 1988) were 
Georges River (Quibray Bay)
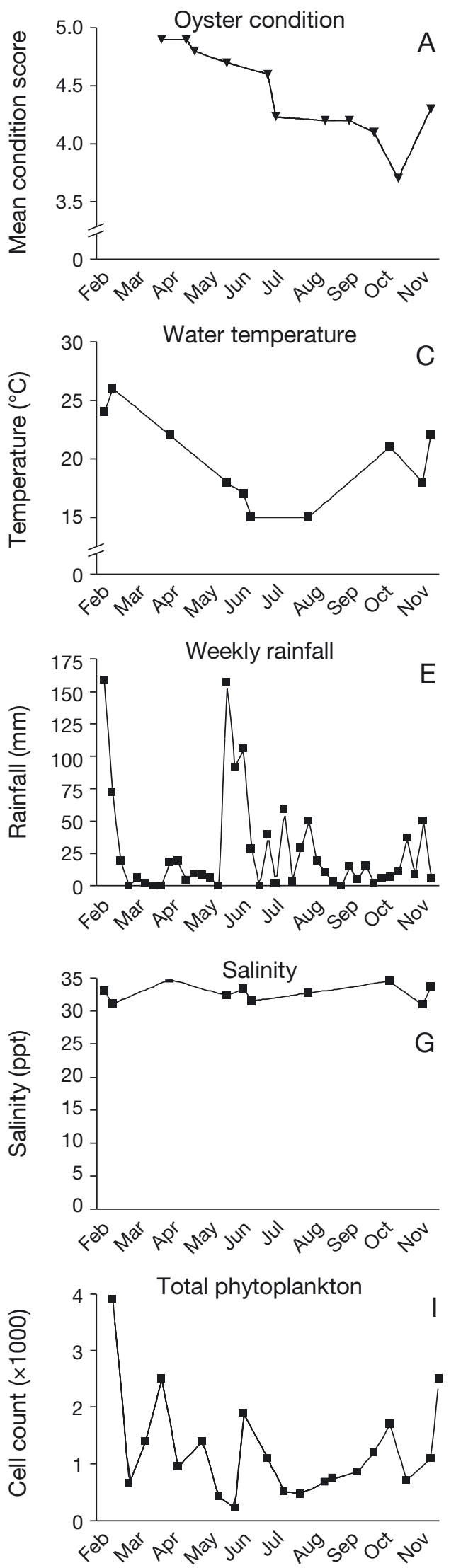

Shoalhaven River (Berrys Bay)
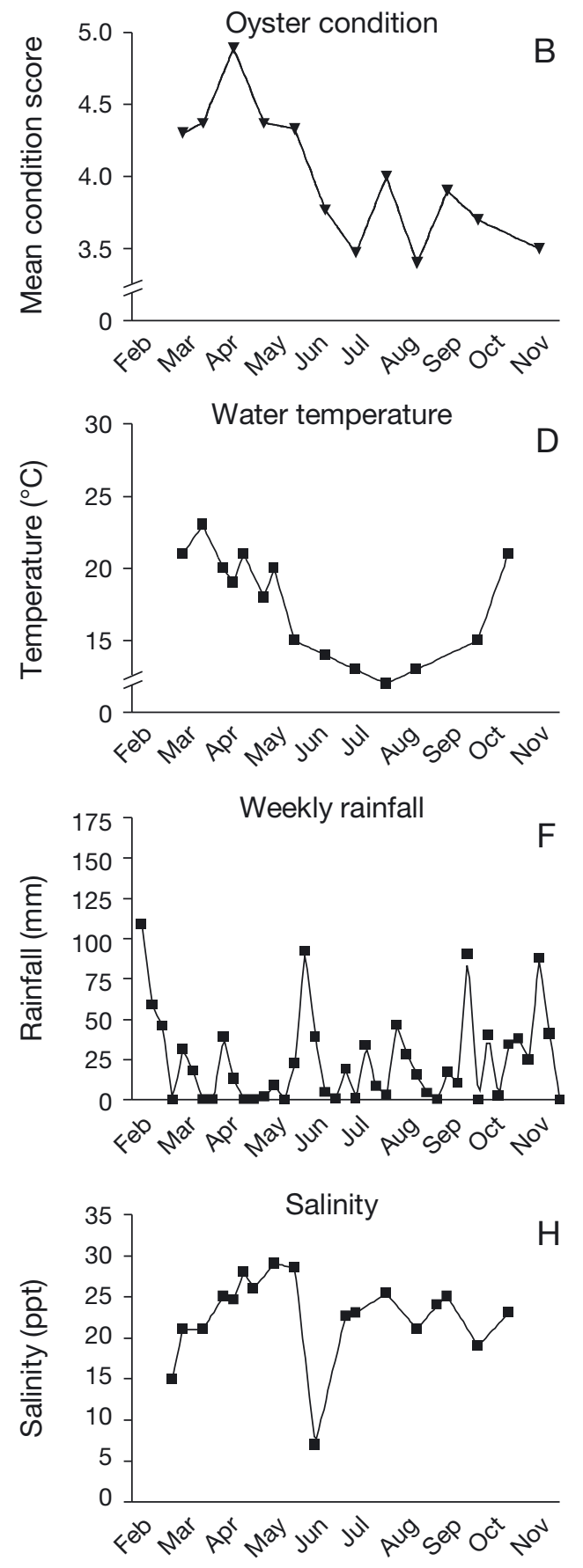

Fig. 2. Key variables examined from February, when experimental oysters were deployed, to November, when the study concluded. Total phytoplankton counts were only available for the Georges River study site 


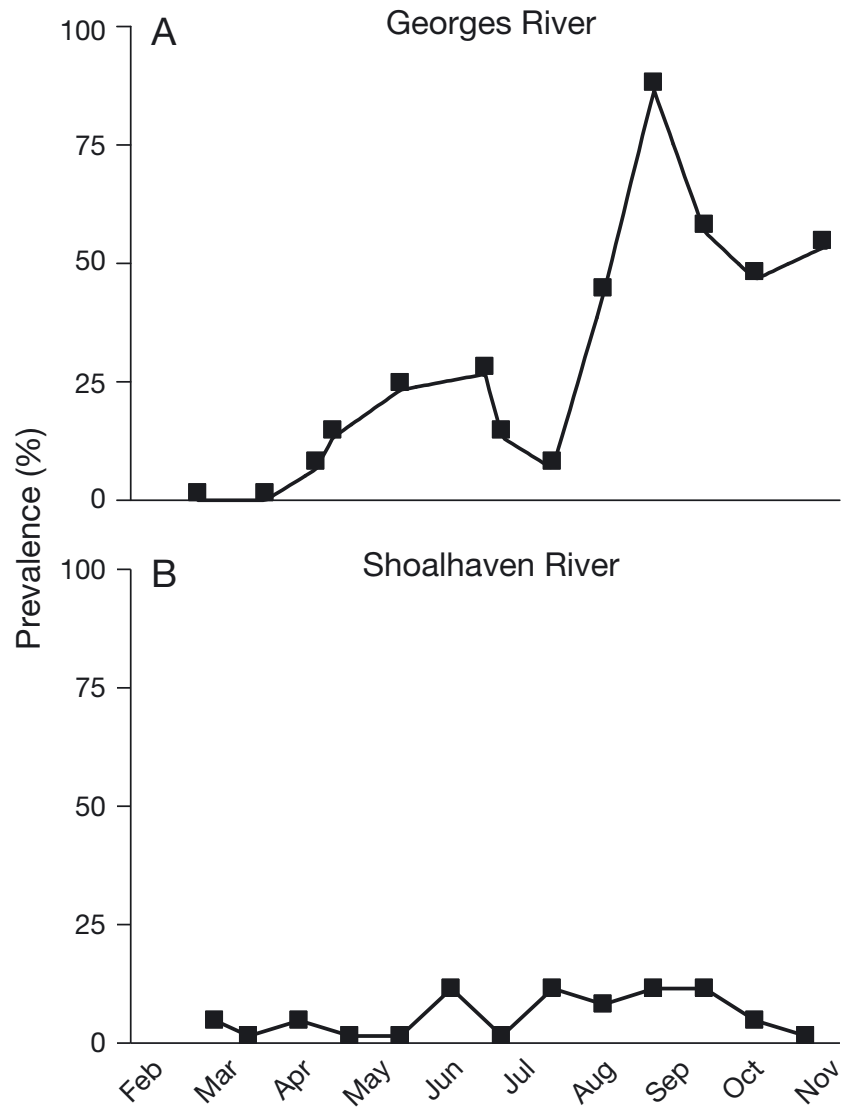

Fig. 3. Saccostrea glomerata. (A) Increase in microscopic lesions consistent with winter mortality (focal abscesses and ulcerations) in samples from the Georges River. (B) Histologic lesions observed in oysters from the Shoalhaven River

visible, with increasing prevalence from August to October. The microcell-like structures were spherical, 1 to $2 \mu \mathrm{m}$ in diameter and contained an eccentric round nucleus and surrounding amphophilic cytoplasm; they were not found in abundance, but were most often located within haemocytes (Fig. 4C). Microcelllike structures associated with the Georges River samples were examined in closer detail with reference to stained sections of the winter mortality type material. Intralesional microcell-like structures identified in this study (Fig. 5A) bear a strong resemblance and are of a similar size to the microcells identified in the disease type material (Fig. 5B).

In comparison to the Georges River oysters, primarily non-specific changes of multifocal mild to moder-

Fig. 4. Saccostrea glomerata. Micrographs showing histological lesions in (A) palps and (B) intestinal tract of oysters sampled from the Georges River (scale bars $=200 \mu \mathrm{m}$ ). (C) Structures consistent with microcells observed in association with lesions in the Georges River samples, often located within haemocytes (arrowhead; scale bar $=20 \mu \mathrm{m}$ ). H: haemocytes;

P: proliferative changes; U: ulcerations; L: gut lumen
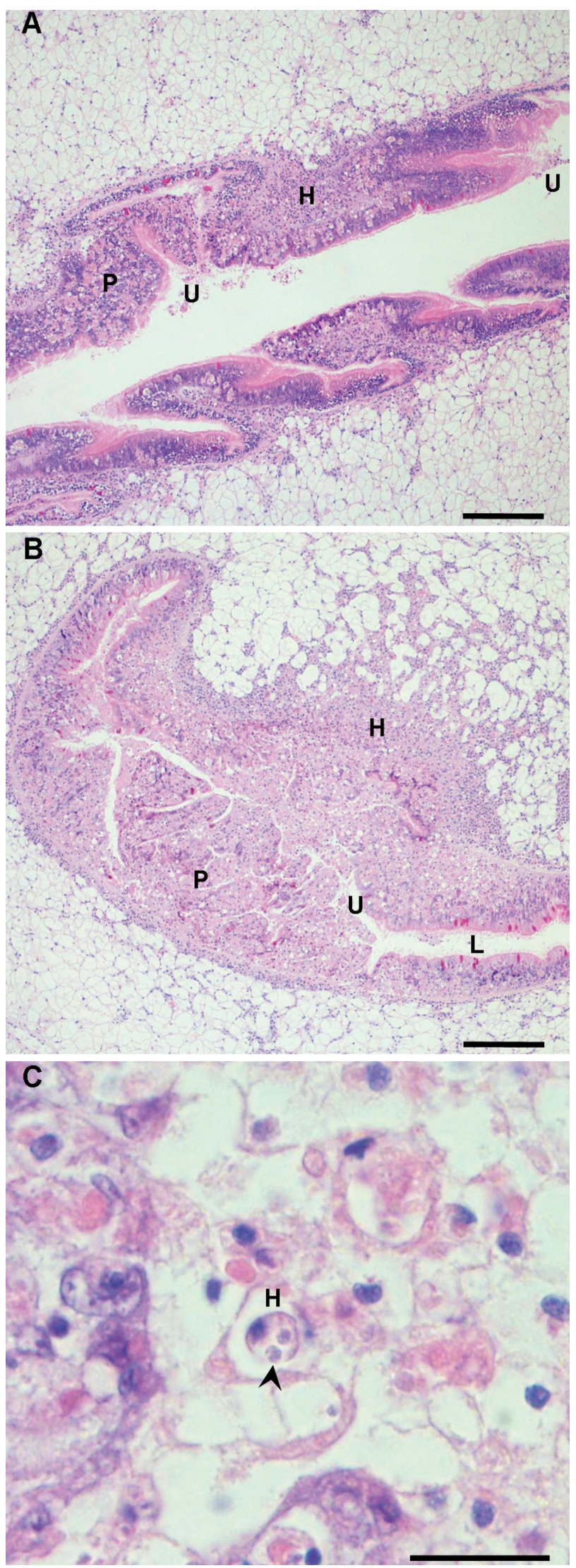
ate haemocytic infiltrates were evident in the oysters examined from the Shoalhaven River. The level of histological abnormalities, predominantly multifocal haemocytic infiltrates, increased throughout the year, with a significant peak in September (data not shown). However, of the 355 oysters examined, only 19 displayed focal lesions that could be considered similar to prior descriptions of winter mortality. These lesions consisted of varying degrees of gut thickening (thickening of the epithelium, occasionally with associated haemocytic infiltrates), with these changes occurring mostly from June to August (Fig. 3B). Microcell-like structures were not observed within these lesions.

We found a modest but highly significant inverse correlation between the presence of histological
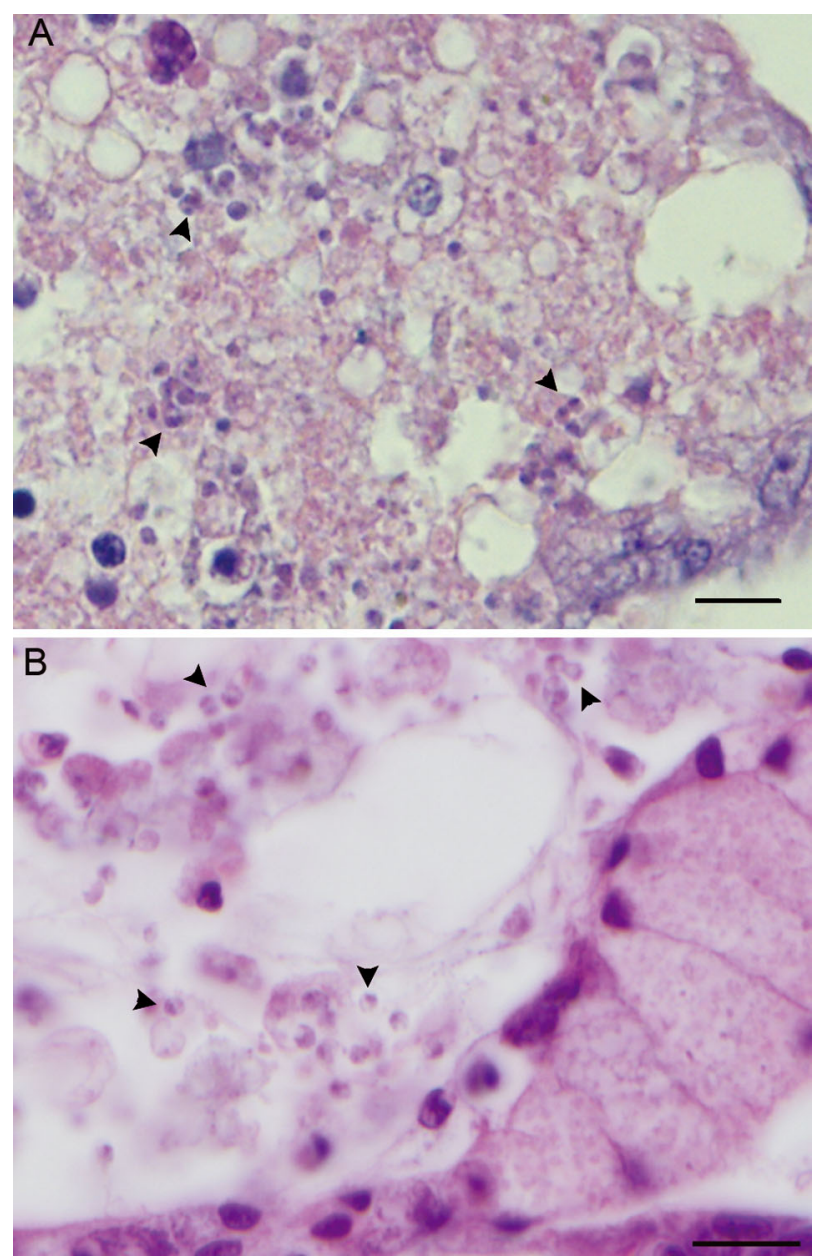

Fig. 5. Saccostrea glomerata. Comparison of H\&E-stained sections of samples collected from the Georges River (A) during this study and (B) in July of 1965. The microcell-like structures (arrowheads) identified in this study closely resemble those identified in the disease type material. Scale bars $=10 \mu \mathrm{m}$ lesions consistent with winter mortality and oyster condition scores in the Georges River oysters ( $\mathrm{r}=$ $-0.29, \mathrm{p}<0.0001)$.

\section{Bonamia sp. PCR and sequence analysis}

All oysters were tested for the presence of a Bonamia sp. using PCR primers specific for the genus (Table 1). While PCR is considered a more sensitive method for parasite detection, a Bonamia sp. was detected only in a small proportion $(10 \%)$ of oysters in the Georges River in 2 samplings during September (Fig. 6A); over the entire study period, only 12 out of a total of 390 (3\%) Georges River samples tested positive for Bonamia sp. This organism was not detected in any oysters from the Shoalhaven River. While there was a temporal relationship between PCR detection of Bonamia sp. in Saccostrea glomerata sampled from the Georges River and the peak in macro- and microscopic lesions consistent with winter mortality, this organism was detected in a far lower percentage of oys-
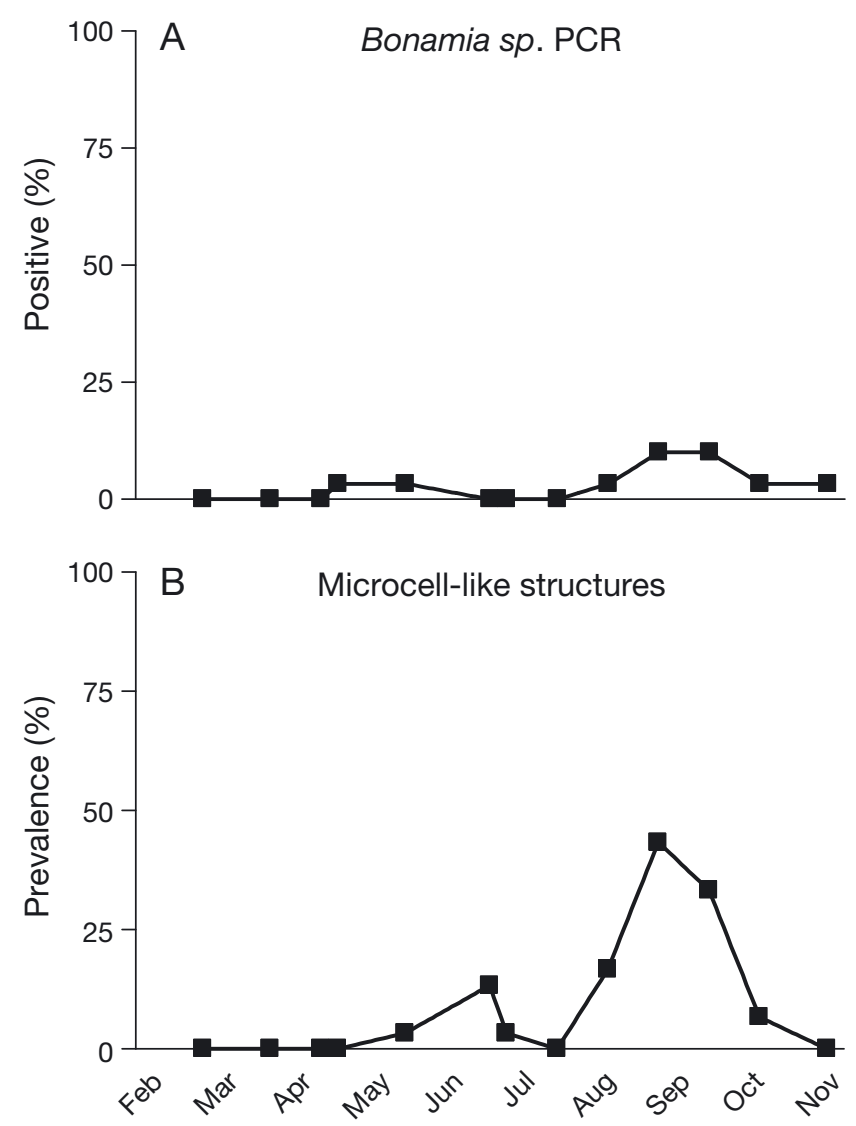

Fig. 6. Saccostrea glomerata. Prevalence of (A) Bonamia sp. as detected by PCR and (B) microcells observed via histopathology in Georges River oyster samples 
ters than those displaying histologic lesions (Figs. 3A \& 6A). Furthermore, observations of microcell-like structures in the same oysters also greatly exceeded the prevalence of Bonamia sp. as detected by PCR; microcell-like structures were observed in up to $50 \%$ of oysters during August and September (Fig. 6B).

The 18S rDNA sequence of the Saccostrea glomerata Bonamia sp. from this study (GenBank accession no. KC578009) was genetically similar to $B$. exitiosa (99.5\% identity to GenBank accession no. AF337563), based on a comparison of $1606 \mathrm{bp}$ of available sequence, and excluding the false insertion region identified previously by Hill et al. (2010). The $S$. glomerata Bonamia sp. was also $99.9 \%$ identical to another sequence of $B$. exitiosa derived from a study of various geographically distributed species of this clade (Hill et al. 2010; GenBank accession no. JF495410), based on 1605 bp of available sequence; and was $99.4 \%$ identical to the published sequence from $B$. roughleyi (Cochennec-Laureau et al. 2003; GenBank accession no. AF508801), based on a comparison of $944 \mathrm{bp}$ of available sequence. These data suggest that the $S$. glomerata Bonamia sp. is a member of the $B$. exitiosa-B. roughleyi clade.

\section{In situ hybridisation}

We employed ISH in an attempt to link the Bonamia sp. that was amplified from the Georges River samples using PCR, to the lesions and the microcell-like structures observed histologically. The probes, which were designed for detection of members of the B. exitiosa-B. roughleyi clade (Hill et al. 2010), were fully complementary to the Saccostrea glomerata Bonamia sp. 18S rRNA sequence. Despite consistent hybridisation of these probes to the positive control sections (Fig. 7A,B), S. glomerata sam-
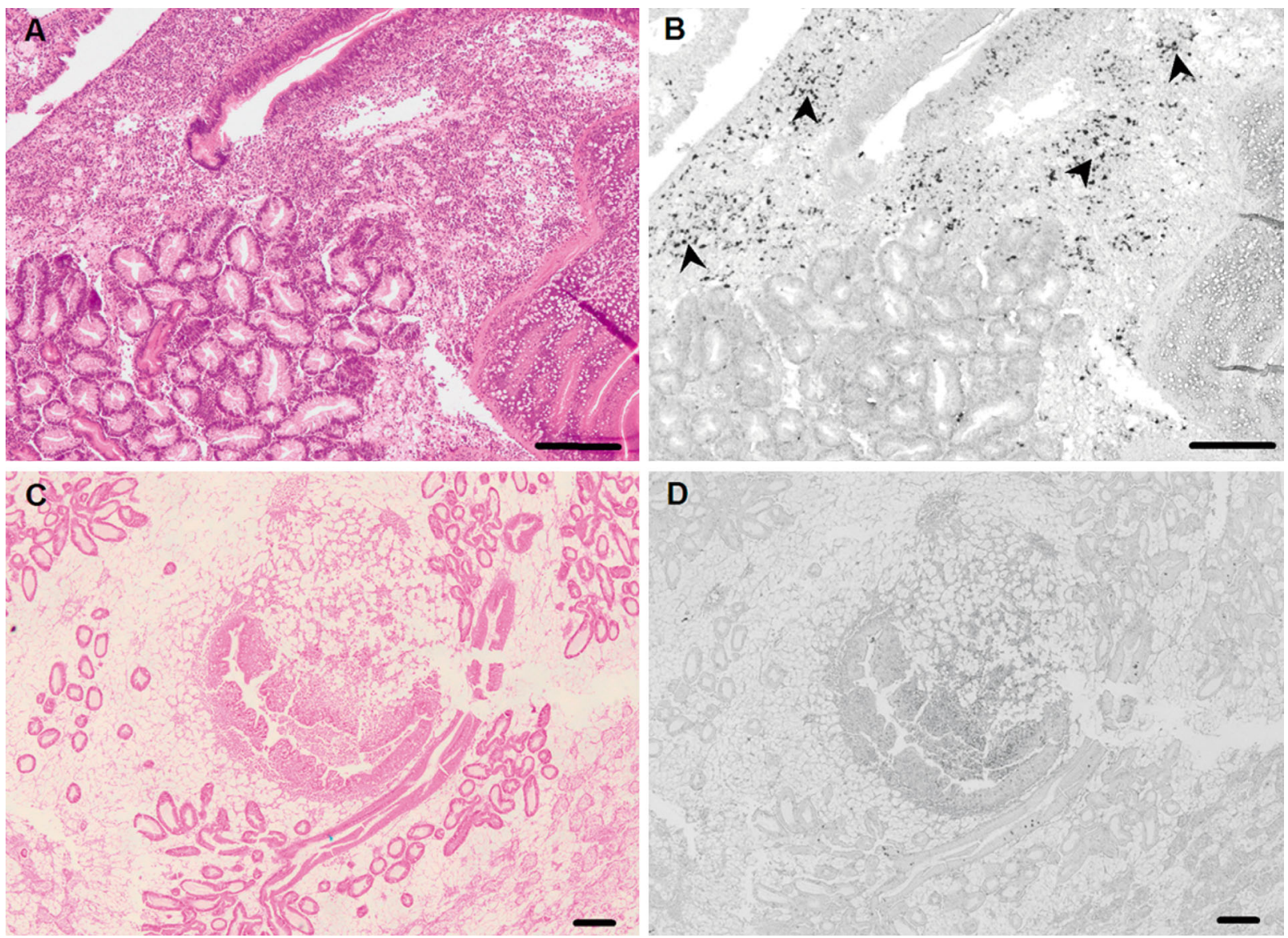

Fig. 7. Crassostrea ariakensis and Saccostrea glomerata. Serial sections of (A,B) Bonamia sp.-positive C. ariakensis and (C,D) Bonamia sp. PCR-positive $S$. glomerata stained with H\&E $(\mathrm{A}, \mathrm{C})$ and via in situ hybridisation (ISH; B,D) using probes specific for the B. exitiosa-B. roughleyi clade. While the control Bonamia-infected C. ariakensis consistently hybridised with the probes (B, arrowheads), ISH failed to detect any Bonamia within S. glomerata samples (D) despite the presence of clear lesions consistent with winter mortality (C). Scale bars $=200 \mu \mathrm{m}$ 
ples from the Georges River, including Bonamia PCR-positive samples as well as sections positive for lesions and microcell-like structures, were all ISH negative (Fig. $7 \mathrm{C}, \mathrm{D}$ ). In contrast, ISH assays conducted with universal eukaryotic probes (Table 1) were all positive, indicating that the sections tested contained intact RNA for hybridisation (data not shown). These data suggested that the Bonamia sp. was not actively infecting the $S$. glomerata tissues.

\section{Further molecular investigations into potential causes of winter mortality}

The relatively high prevalence $(\sim 50 \%)$ of microcell-like structures in Saccostrea glomerata from the Georges River during September led us to further investigate their identity. Initially, we speculated that these microcell-like structures may represent another member of the phylum Haplosporidia (Carnegie \& Cochennec-Laureau 2004, López-Flores et al. 2007). A generic haplosporidian PCR assay (Table 1) yielded a number of amplicons from both Georges and Shoalhaven River S. glomerata samples. Sequence analyses of these amplicons indicated that (1) samples that were previously identified as PCR-positive for the Bonamia sp. were also positive in the generic haplosporidian assay, although no additional Bonamia sp. positives were detected, and (2) an organism similar to Haplosporidium costale (99.3\% identical to GenBank accession no. AF387122) was detected in a number of oysters. This sequence identity is based on a partial $18 \mathrm{~S}$ rDNA sequence which has been deposited in GenBank (accession no. KC578010). PCR primers specifically designed for the amplification of the Haplosporidium sp. (Table 1) were then used to retest all S. glomerata DNA samples, and revealed a relatively high prevalence of this organism amongst Georges and Shoalhaven River samples (Fig. 8). Despite a moderate to high PCR prevalence of the Haplosporidium sp. in oysters at various times over the study period, including during September when lesions were most evident, it was noted that PCR amplicons were generally weak and perhaps not indicative of active infection. Consistent with this view was a lack of histological evidence of plasmodia suggestive of a haplosporidian in PCR-positive oysters. ISH assays performed on PCR-positive and/or lesion-positive tissues employing a probe specific for $H$. costale were also negative, while positive control sections included in the same assay were positive (data not shown).

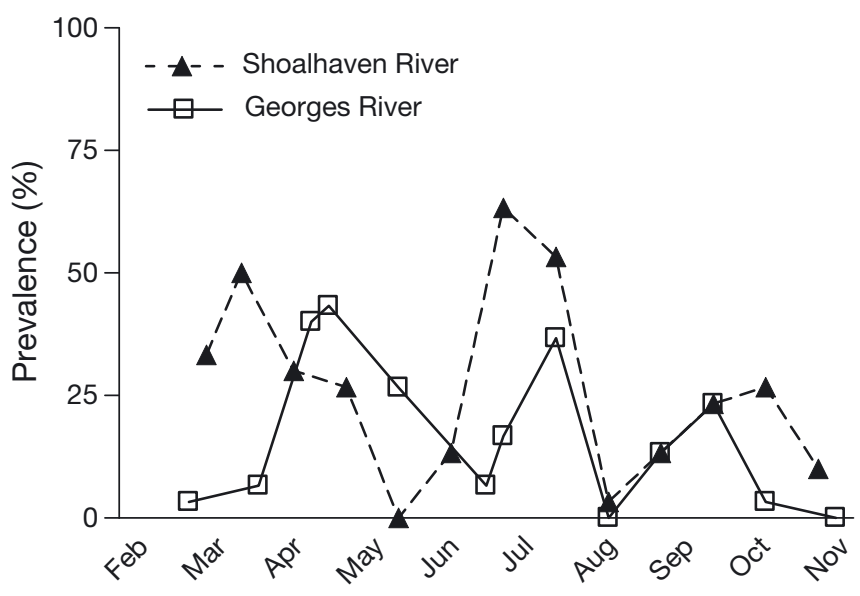

Fig. 8. Haplosporidium sp. infecting Saccostrea glomerata. Prevalence of a Haplosporidium sp. in oyster samples collected from the Georges and Shoalhaven Rivers, as determined by PCR

Because the Georges River is an estuary affected by QX disease (Adlard \& Ernst 1995), we wished to rule out involvement of the QX parasite, Marteilia sydneyi, in the observed disease process. QX sporonts were not detected in Saccostrea glomerata tissue sections; however, we also wished to rule out the persistence of other developmental stages of this parasite using molecular methods (Table 1). All Georges River samples collected during the peak pathology period (September) tested negative for the presence of M. sydneyi. In addition, a universal (nonmetazoan) PCR assay (Table 1) that had been successfully employed by Carnegie et al. (2003) was attempted, but did not yield any specific amplicons. Amplification of Mikrocytos using generic primers for this genus (Carnegie et al. 2003) was also unsuccessful, although it should be noted that no positive control material was available to fully verify the results of this assay.

\section{DISCUSSION}

This is the first longitudinal study of winter mortality that attempts to bring together field observations, epidemiological data, histopathology and molecular investigations. Despite the fact that Saccostrea glomerata from both estuaries experienced mortalities, gross clinical signs consistent with prior descriptions of winter mortality were evident only in samples from the Georges River, the estuary where the disease was first described (Roughley 1926). Microscopic lesions within these oysters were first noted in April and May, with pathological changes peaking in Septem- 
ber. This pattern of disease is consistent with prior studies indicating that the disease is most severe in late winter and early spring (Roughley 1926, Nell 2001, 2007), and with anecdotal evidence from oyster growers that stock relocation must occur in late autumn to avoid disease onset (Smith et al. 2000, Nell 2001).

Prior studies have shown that triploid, as opposed to diploid, Saccostrea glomerata cultivated in all but the most southern of NSW estuaries maintain condition throughout the winter months (Hand \& Nell 1999) due to retarded gametogenesis (Cox et al. 1996). In our study, we found that oyster condition score decreased in Georges River oysters during the winter months and that there was a significant, although modest, inverse correlation between the presence of histological lesions and oyster condition. It is possible that these pathological changes contributed, amongst other factors, to the decline in oyster condition. Histological changes in Georges River oysters were mostly internal, with hyperplastic enteritis and ulceration affecting the stomach and intestinal epithelium (although other tissues such as the palps and gills were also represented). Oyster morbidity and mortality would not be unexpected given the nature (enteritis), severity and prevalence of these lesions and their potential impact on nutrient uptake. The peak in disease severity also coincided with low levels of phytoplankton, a major food source for $S$. glomerata, which may have further impacted on oyster nutrition. Low phytoplankton levels occur as a function of low water temperatures and low rainfall, which decrease nutrient load (Paerl et al. 2010). As observed in this study, these conditions are most often met during the winter months in NSW. Indeed, dry autumns and winters have been traditionally associated with an increased incidence of winter mortality (Hand et al. 1998). Further work is required to determine whether declining oyster condition occurs as a consequence of winter mortality or is a potential predisposing factor for disease under particular environmental conditions.

A decline in oyster condition was also noted in the Shoalhaven River samples, despite little evidence of gross clinical or histological signs of winter mortality. This suggests that factors other than winter mortality were responsible for the mortalities in the Shoalhaven River, such as unfavourable environmental conditions. In this estuary, as in the Georges River, there was a temporal relationship between declining oyster condition and decreasing water temperatures; however, salinity recorded at the 2 study sites differed considerably. The Berrys Bay (Shoalhaven) site exhibited lower salinity over the entire study period but considerably higher variability. These observations can be explained in terms of the different geomorphology of the 2 study sites. Quibray Bay has a relatively small catchment area, is situated near the confluence of Botany Bay and the Tasman Sea and has limited tidal exchange with Botany Bay due to sand shoaling at its entrance. It appears that these features result in relatively stable salinity levels. In contrast, salinity at Berrys Bay was more markedly impacted by rainfall events due to the fact that this site is located some distance upriver. This also accounts for the generally lower salinity observed in Berrys Bay (<30 ppt) for the entire study period, a level which would not be considered optimal for Bonamia parasites (Audemard et al. 2008) or winter mortality disease (Wolf 1967), which has traditionally been associated with high (30-35 ppt) salinities (Farley et al. 1988). Nonetheless, the large fluctuations in salinity observed at this site during June of 2010 were unlikely to be favourable for oyster health, given that low salinities result in immune suppression in Saccostrea glomerata (Butt et al. 2006, Green \& Barnes 2010).

Given that 'Bonamia sp.' and B. exitiosa are on Australia's National List of Reportable Diseases of Aquatic Animals, their role (if any) in winter mortality needs to be elucidated. Indeed, this study raises doubts about the role of a Bonamia sp. in the pathogenesis of winter mortality. Prior studies have consistently demonstrated the superior sensitivity of molecular techniques for the detection of Bonamia spp. over histological diagnosis (Diggles et al. 2003, Marty et al. 2006). While a member of the $B$. exitiosa-B. roughleyi clade was detected via PCR in a small proportion of Saccostrea glomerata from the Georges River $(3 \%)$, the low prevalence of this organism cannot reasonably account for the relatively high prevalence (>85\% during September) of focal abscesses and ulcerations characteristic of winter mortality. Nonetheless, microcell-like structures similar to those described by Farley et al. (1988) in the disease type material were often observed in association with microscopic lesions, suggesting that a protozoal parasite may be involved in the disease. Curiously, no prior studies linking $B$. roughleyi to winter mortality have sought to undertake ISH on suspect material using Bonamia-specific probes. In this study, we undertook such experiments but were unable to demonstrate the presence of a Bonamia sp. within lesions. It would be of considerable interest to conduct similar experiments on the type material for winter mortality (Farley et al. 1988) in which the microcells were first described. 
It appears that the PCR detection of Bonamia sp. is an incidental finding of an organism that nonetheless resides in high salinity areas of the Georges River. A similar finding of a genetically indistinguishable Bonamia sp. in Australian flat oysters Ostrea angasi from Merimbula Lake was made previously, apparently in the absence of clinical disease (Corbeil et al. 2006). Our finding of a relatively high prevalence of a Haplosporidium costale-like organism in both the Georges and Shoalhaven River oysters, despite any histological evidence for infection, further demonstrates the fact that organisms considered pathological in some species may not necessarily be associated with clinical disease in others. The fact that PCR detection of both a Bonamia sp. and a Haplosporidium sp. were made in this study in the absence of positive ISH results suggests that these organisms may simply be present in the water that bathes or is filtered through the oysters. Despite the low level of detection of Bonamia sp. in the Georges River, it may be of interest to test Pacific oysters Crassostrea gigas, which are cultivated alongside Saccostrea glomerata in this estuary, since C. gigas has been implicated as a reservoir for Bonamia spp. (Lynch et al. 2010).

Our inability to make a causal link between the Bonamia sp. and winter mortality raises questions about the identity of the microcell-like structures observed in histological sections. Despite a number of molecular investigations into the nature of these structures, we were unable to positively identify them. PCR assays designed to detect a broad range of haplosporidians did not reveal the presence of any additional species aside from the already identified Bonamia sp. and the Haplosporidium sp. These results suggest that the microcell-like structures may not even represent a member of the Haplosporidia. These cells appear to represent a protist from an as yet unidentified group.

A Sydney rock oyster breeding programme has been breeding for resistance to winter mortality using mass selection in the Georges River since 1990 (Nell et al. 2000). Quibray Bay is the primary site used to expose broodstock to this disease and has produced lines of oysters where losses attributable to this disease have been reduced by more than half over 4 generations (Dove et al. 2013). A greater understanding of the factors responsible for winter mortality disease is critical to further increase the robustness of these genetic lines, elucidate the mechanisms for disease resistance and ensure that genetic gains made in Georges River are transferrable to other estuaries affected by this disease.
Acknowledgements. This work was supported by a grant to C.J. by the Hermon Slade Foundation. We thank the Georges River oyster growers (R., L. and T. Drake) and Shoalhaven River oyster farmers (J. and A. Collison and L. De Soto) for participating in this study and for their assistance with sample collection. A. Zammit from the NSW Food Authority is gratefully acknowledged for providing the temperature, salinity and phytoplankton data for the Quibray Bay study site. We also acknowledge the Histology Unit at EMAI for their assistance with sample processing.

\section{LITERATURE CITED}

Adlard RD, Ernst I (1995) Extended range of the oyster pathogen Marteilia sydneyi. Bull Eur Assoc Fish Pathol 15:119-121

Amann RI, Binder BJ, Olson RJ, Chisholm SW, Devereux R, Stahl DA (1990) Combination of 16S rRNA-targeted oligonucleotide probes with flow cytometry for analyzing mixed microbial populations. Appl Environ Microbiol 56: 1919-1925

Audemard C, Carnegie RB, Stokes NA, Bishop MJ, Peterson $\mathrm{CH}$, Burreson EM (2008) Effects of salinity on Bonamia sp. survival in the Asian oyster Crassostrea ariakensis. J Shellfish Res 27:535-540

Bower SM (2012) Synopsis of infectious diseases and parasites of commercially exploited shellfish: Bonamia (=Mikrocytos) roughleyi (Australian Winter Disease) of oysters. Fisheries and Oceans Canada. Available at www. pac.dfo-mpo.gc.ca/science/species-especes/shellfishcoquillages/diseases-maladies/pages/mikrouoy-eng.htm (accessed 4 March 2013)

Bower SM, Hervio D, Meyer GR (1997) Infectivity of Mikrocytos mackini, the causative agent of Denman Island disease in Pacific oysters Crassostrea gigas, to various species of oysters. Dis Aquat Org 29:111-116

> Brock V (1990) Intergeneric distances between Ostrea, Crassostrea, and Saccostrea, studied by means of crossed immuno-electrophoresis. Mar Ecol Prog Ser 68:59-63

Butt D, Shaddick K, Raftos D (2006) The effect of low salinity on phenoloxidase activity in the Sydney rock oyster, Saccostrea glomerata. Aquaculture 251:159-166

Cannon RM, Roe RT (1982) Livestock disease surveys: a field manual for veterinarians. Bureau of Rural Science, Department of Primary Industry. Australian Government Publishing Service, Canberra

> Carnegie RB, Cochennec-Laureau N (2004) Microcell parasites of oysters: recent insights and future trends. Aquat Living Resour 17:519-528

Carnegie RB, Meyer GR, Blackbourn J, Cochennec-Laureau N, Berthe FCJ, Bower SM (2003) Molecular detection of the oyster parasite Mikrocytos mackini, and a preliminary phylogenetic analysis. Dis Aquat Org 54:219-227

Cochennec N, Renault T, Boudry P, Chollet B, Gerard A (1998) Bonamia-like parasite found in the Suminoe oyster Crassostrea rivularis reared in France. Dis Aquat Org 34:193-197

Cochennec-Laureau N, Reece KS, Berthe FCJ, Hine PM (2003) Mikrocytos roughleyi taxonomic affiliation leads to the genus Bonamia (Haplosporidia). Dis Aquat Org 54:209-217

Corbeil S, Arzul I, Robert M, Berthe FCJ, Besnard-Cochennec N, Crane MSJ (2006) Molecular characterisation of an Australian isolate of Bonamia exitiosa. Dis Aquat Org 71:81-85 
Cox ES, Smith MSR, Nell JA, Maguire GB (1996) Studies on triploid oysters in Australia. VI. Gonad development in diploid and triploid Sydney rock oysters Saccostrea commercialis (Iredale and Roughley). J Exp Mar Biol Ecol 197:101-120

Diggles BK, Cochennec-Laureau N, Hine PM (2003) Comparison of diagnostic techniques for Bonamia exitiosus from flat oysters Ostrea chilensis in New Zealand. Aquaculture 220:145-156

> Dove MC, Nell JA, O'Connor WA (2013) Evaluation of the progeny of the fourth-generation Sydney rock oyster Saccostrea glomerata (Gould, 1850) breeding lines for resistance to QX disease (Marteilia sydneyi) and winter mortality (Bonamia roughleyi). Aquaculture Res 44: 1791-1800

Farley CA, Wolf PH, Elston RA (1988) A long-term study of 'microcell' disease in oysters with a description of a new genus, Mikrocytos (g. n.), and two new species, Mikrocytos mackini (sp. n.) and Mikrocytos roughleyi (sp. n.). Fish Bull 86:581-593

- Gagné N, Cochennec N, Stephenson M, McGladdery S, Meyer GR, Bower SM (2008) First report of a Mikrocytoslike parasite in European oysters Ostrea edulis from Canada after transport and quarantine in France. Dis Aquat Org 80:27-35

> Giovannoni SJ, DeLong EF, Olsen GJ, Pace NR (1988) Phylogenetic group-specific oligodeoxynucleotide probes for identification of single microbial cells. J Bacteriol 170: 720-726

Green TJ, Barnes AC (2010) Reduced salinity, but not estuarine acidification, is a cause of immune-suppression in the Sydney rock oyster Saccostrea glomerata. Mar Ecol Prog Ser 402:161-170

Hand R, Nell JA (1999) Studies on triploid oysters in Australia: XII. Gonad discolouration and meat condition of diploid and triploid Sydney rock oysters (Saccostrea commercialis) in five estuaries in New South Wales, Australia. Aquaculture 171:181-194

Hand R, Nell JA, Smith IR, Maguire GB (1998) Studies on triploid oysters in Australia. XI. Survival of diploid and triploid Sydney rock oysters (Saccostrea commercialis (Iredale and Roughley)) through outbreaks of winter mortality caused by Mikrocytos roughleyi infestation. J Shellfish Res 17:1129-1135

- Hill KM, Carnegie RB, Aloui-Bejaoui N, El Gharsalli R, White DM, Stokes NA, Burreson EM (2010) Observation of a Bonamia sp. infecting the oyster Ostrea stentina in Tunisia, and a consideration of its phylogenetic affinities. J Invertebr Pathol 103:179-185

> Hine PM, Bower SM, Meyer GR, Cochennec-Laureau N, Berthe FCJ (2001) Ultrastructure of Mikrocytos mackini, the cause of Denman Island disease in oysters Crassostrea spp. and Ostrea spp. in British Columbia, Canada. Dis Aquat Org 45:215-227

Kleeman SN, Adlard RD (2000) Molecular detection of Marteilia sydneyi, pathogen of Sydney rock oysters. Dis Aquat Org 40:137-146

Kleeman SN, Adlard RD, Lester RJG (2002) Detection of the initial infective stages of the protozoan parasite Marteilia sydneyi in Saccostrea glomerata and their development through to sporogenesis. Int J Parasitol 32:767-784

Lauckner G (1983) Diseases of Mollusca: Bivalvia. In: Kinne O (ed) Diseases of marine animals, Vol 2. Biologische

Editorial responsibility: Marc Engelsma,

Lelystad, The Netherlands
Anstalt Helgoland, Hamburg, p 447-961

López-Flores L, Suarez-Santiago VN, Longet D, Saulnier D, Chollet B, Arzul I (2007) Characterization of actin genes in Bonamia ostreae and their application to phylogeny of the Haplosporidia. Parasitology 134:1941-1948

Lynch SA, Abollo E, Ramilo A, Cao A, Culloty SC, Villalba A (2010) Observations raise the question if the Pacific oyster, Crassostrea gigas, can act as either a carrier or a reservoir for Bonamia ostreae or Bonamia exitiosa. Parasitology 137:1515-1526

Marty GD, Bower SM, Clarke KR, Meyer G and others (2006) Histopathology and a real-time PCR assay for detection of Bonamia ostreae in Ostrea edulis cultured in western Canada. Aquaculture 261:33-42

> Medlin L, Elwood HJ, Stickel S, Sogin ML (1988) The characterization of enzymatically amplified eukaryotic 16Slike rRNA-coding regions. Gene 71:491-499

Nell JA (2001) The history of oyster farming in Australia. Mar Fish Rev 63:14-25

Nell JA (2007) Primefacts: diseases of Sydney rock oysters. NSW Department of Primary Industries. Available at www.dpi.nsw.gov.au/_data/assets/pdf_file/0004/16418 2/Diseases-of-Sydney-rock-oysters.pdf (accessed 4 Mar 2013)

> Nell JA, Perkins B (2006) Evaluation of the progeny of thirdgeneration Sydney rock oyster Saccostrea glomerata (Gould, 1850) breeding lines for resistance to QX disease Marteilia sydneyi and winter mortality Bonamia roughleyi. Aquacult Res 37:693-700

Nell JA, Smith IR, McPhee CC (2000) The Sydney rock oyster Saccostrea glomerata (Gould 1850) breeding programme: progress and goals. Aquacult Res 31: 45-49

O'Neill RM (2011) A preliminary study assessing sub-lethal environmental water quality parameters on Sydney rock oyster (Saccostrea glomerata) performance in the Shoalhaven and Crookhaven River systems, NSW, Australia. BSc thesis, University of Wollongong

Paerl HW, Rossignol KL, Hall SN, Peierls BL, Wetz MS (2010) Phytoplankton community indicators of short- and long-term ecological change in the anthropogenically and climatically impacted Neuse River Estuary, North Carolina. Estuaries Coasts 33:485-497

Renault T, Stokes NA, Chollet B, Cochennec N, Berthe F, Gérard A, Burreson EM (2000) Haplosporidiosis in the Pacific oyster Crassostrea gigas from the French Atlantic coast. Dis Aquat Org 42:207-214

Roughley TC (1926) An investigation of the cause of an oyster mortality on the Georges River, New South Wales, 1924-5. Proc Linn Soc NSW 51:446-491

Smith IR, Nell JA, Adlard RD (2000) The effect of growing height and growing method on winter mortality in diploid and triploid Sydney rock oysters, Saccostrea glomerata (Gould, 1850). Aquaculture 185:197-205

Stokes NA, Burreson EM (1995) A sensitive and specific DNA probe for the oyster pathogen Haplosporidium nelsoni. J Eukaryot Microbiol 42:350-357

Stokes NA, Burreson EM (2001) Differential diagnosis of mixed Haplosporidium costale and Haplosporidium nelsoni infections in the eastern oyster, Crassostrea virginica, using DNA probes. J Shellfish Res 20:207-213

Wolf PH (1967) Winter mortality hits state's oyster output. Fisherman 2:20-22

Submitted: March 4, 2013; Accepted: June 11, 2013

Proofs received from author(s): October 23, 2013 